\title{
GLOBALIZATION MYTHS: SOME HISTORICAL REFLECTIONS ON INTEGRATION, INDUSTRIALIZATION AND GROWTH IN THE WORLD ECONOMY
}

\author{
Paul Bairoch and \\ Richard Kozul-Wright
}

No. 113

March 1996

This paper was prepared for the WIDER Conference on Transnational Corporations and the Global Economy, Kings College, Cambridge (UK), September 1995. The authors would like to acknowledge the comments of Mica Panic, Paul Rayment, Rugerio Studart, Bob Rowthorn and Ha-Joon Chang on earlier drafts of this paper. 
The opinions expressed in this paper are those of the authors and do not necessarily reflect the views of UNCTAD. The designations and terminology employed are also those of the authors.

UNCTAD Discussion Papers are read anonymously by at least one referee, whose comments are taken into account before publication.

Comments on this paper are invited and should be addressed to the authors, c/o Editorial Assistant, Editorial Board, Office E-9013, United Nations Conference on Trade and Development (UNCTAD), Palais des Nations, 1211 Geneva 10, Switzerland. Copies of the UNCTAD Review, Discussion Papers and Reprint Series may also be obtained from this address (Tel. No. 022-907.5733, Fax No. 022-907.0043). 


\section{CONTENTS}

Chapter

Page

INTRODUCTION

I. GLOBALIZATION

II. TRENDS IN INTERNATIONAL PRODUCTION AND FINANCE BEFORE 1914

III. INDUSTRIALIZATION AND THE NEW INTERNATIONAL DIVISION OF LABOUR

IV. GROWTH AND CONVERGENCE IN THE WORLD ECONOMY BEFORE 1913

V. CONCLUSION

REFERENCES 


\title{
GLOBALIZATION MYTHS: SOME HISTORICAL REFLECTIONS ON INTEGRATION, INDUSTRIALIZATION AND GROWTH IN THE WORLD ECONOMY
}

\author{
Paul Bairoch and Richard Kozul-Wright
}

\begin{abstract}
It has become popular to draw a parallel between current globalization trends and the half century of international economic integration before the First World War. Indeed, some writers suggest that current trends mark a return to this earlier period, from which they draw strong conclusions about growth prospects and convergence associated with globalization. This paper assesses this historical parallel. It accepts that many features of today's international economy are not unique. However, it is sceptical of efforts to make a direct parallel with the earlier period. In particular, the paper shows that the period before 1913 was not one of trade liberalization, nor one of reduced expectations about the role of the State, and suggests that rapid industrial growth in some economies cannot be explained by globalization pressures. More generally, a description of this earlier period of globalization as one of rapid growth and convergence is questioned, and instead associated with uneven economic development, during which a very small group of countries were able to reinforce their domestic growth efforts through links to the international economy, while for others these same links did little to alter long-term growth prospects, and in some cases even hindered them.
\end{abstract}

\section{INTRODUCTION}

The "short twentieth century" has ended unexpectedly (Hobsbawm, 1994a). The economic shocks of the late 1960s and early 1970s not only brought to an abrupt halt three decades of unprecedented economic growth and stability, they also weakened many of the institutional structures which had come to define the century's evolution. The subsequent emergence of a neoliberal agenda in the leading industrial countries, reinforced by the fall of communism, made the removal of these same structures a condition of economic recovery and simultaneously identified a series of powerful economic forces pushing towards a new international economic order where national boundaries, State structures and domestic economic policies are of ever diminishing importance. Open markets, transnational corporations and new information technologies have, on this account, become the new forces for economic growth and development in a truly global economy. Through various channels these same forces have had a profound influence on the policies pursued by many developing countries (Chang and Rowthorn, 1995). Globalization entered the political and academic vocabulary, in part, to describe the

\footnotetext{
Respectively, University of Geneva and UNCTAD, Geneva. The co-authoring of this paper has to a large extent followed Adam Smith's longstanding advice on the benefits of specialization. The empirical work for this paper draws heavily on the cumulative research of Paul Bairoch. The storyline was, largely, the responsibility of Richard Kozul-Wright.
} 
speed and intensity of these changes. But it was also intended to suggest that the late 20th century was entering a distinct and unchartered era of economic development.

However, the idea that global economic integration describes a wholly new stage of world development has not received universal acceptance. Some economic historians from the Annales School and elsewhere have described the emergence of a world economy beginning in the 15th century. More recently the period in the half century before the First World War has become a favourite historical vantage point from which to survey current trends in the world economy and its future prospects; those more on the left to highlight the eternal contradictions of capitalism, those on the right to make the case that growth and market openness are irrevocably linked. This paper addresses the historical parallel between the contemporary era and the pre-First World War period. However, our approach is unconventional. One of the authors of this paper has elsewhere noted the extent to which economic history has become the source of "myths" for contemporary economic theorists and policy makers (Bairoch, 1993) and this theme underpins the arguments developed in this paper. Indeed, because many of these myths have obscured the real dynamics of international economic relations, we believe the paramount challenge for economic historians looking at globalization is to distinguish myths and realities.

We begin with some general remarks aimed at identifying a strong globalization thesis around which a number of economic myths have emerged. The second part looks at the internationalization of production and financial activities between 1870 and 1913 with the aim of distinguishing the myths from the reality of an emerging international division of labour. The third part is concerned with whether the way in which national economies became part of the new international division of labour mattered to their growth and development prospects. This involves sifting through some of the myths that have emerged around late industrialization. The final part asks whether the combination of forces associated with international integration and industrialization in the late 19th century produced the kind of development paths expected from globalization in the late 20th century. This leads us to examine the myths surrounding economic growth before the First World War.

\section{GLOBALIZATION}

Globalization ideas can claim an impressive intellectual ancestry, including Adam Smith, Marx and John Stuart Mill, Hecksher and Ohlin, John Maynard Keynes and Lenin, to name only the most distinguished. Perhaps not surprisingly given this diverse list of thinkers, beyond a broad agreement that economic activity has a tendency to expand beyond its initial national setting, connecting a growing number of more widely dispersed economic locations, most contemporary observers have differed in 
their description of the globalization process, and have failed to construct a consistent theoretical explanation of what is driving it and where it might be going. In part, this struggle to construct a coherent framework reflects terminological confusion over the closely related but nevertheless distinct concepts of openness, integration and interdependence (Panic, 1995). In part, it reflects, theoretical problems in linking trade, capital flows and foreign direct investment (FDI) (Akyüz, 1995). But this also reflects important differences over whether economic integration is dominated by forces which make for a smooth and continuous process, or for a discontinuous and conflictual one. This paper seeks to tackle some of these issues from an historical perspective. However, it is necessary to begin with some more general observations on the current globalization literature.

In the first place, inadequate consideration has been given in much of this literature to the fact that globalization identifies both a process in which the production and financial structures of countries are becoming interlinked by an increasing number of cross-border transactions to create an international division of labour in which national wealth creation comes, increasingly, to depend on economic agents in other countries, and the ultimate stage of economic integration where such dependence has reached its spatial limit. However, what this global economy actually looks like has not received the attention that it merits (Gordon, 1988). Strictly speaking a truly global economy is one dominated by transnational firms and financial institutions, operating in world markets independently of national boundaries, national political objectives and domestic economic constraints (Bryant, 1980, pp. 140-42). Defined in this way, the spread of market relations describes only one part of the globalization process, and, arguably, not the most important one. Rather, capital mobility, because of its potential to connect markets and production in a more direct, more complex and much deeper manner than other crossborder flows, emerges as a more significant influence on global economic integration.

However, introducing capital mobility is far from satisfactory for analysing globalization. Economists have never been very comfortable with the concept of capital and while it does imply a more direct focus on the firm as the vehicle for globalization, the concept of the firm has itself had a somewhat shadowy existence in economic discourse. ${ }^{1}$ Indeed, there is a dilemma running across much of the globalization literature between resting the analysis on the logic of the market - which hinges on price coordination - and the logic of the firm - which is based on the failure of such coordination. Still, making capital mobility the entry point into a discussion of gobalization is useful in highlighting the distinction between production (trade and investment) and financial activities in the integration process.

Another theme running across much of the recent globalization literature suggests that the combined pressure of capital mobility, technological progress and heightened market competition

To mention just one of the difficulties of discussing globalization in the absence of an adequate theoretical analysis of the firm, most of the recent analysis of the expanding role of transnational corporations has ignored profit (and rent) seeking in shaping global dynamics (Kozul-Wright, 1995a), which in turn can be linked to the absence of an adequate theory of FDI in most of the globalization literature (Akyüz, 1995). 
describes an irreversible force beyond the influence of domestic policy makers. With the introduction of this policy context, globalization is often used as a synonym for greater openness and closely linked to the liberalization of domestic and foreign transactions. Thus behind the basic disagreement as to whether globalization will lead to immiserization and economic crisis or to faster economic growth and convergence, there is a widely shared assumption that the role of the State in managing economic activity has already diminished under globalization pressures and will become irrelevant in the truly global economy.

All these themes have received further elaboration with the recognition among economists that global integration is not a new feature of the world economy and that the half century leading up to the First World War might hold some useful lessons for understanding the current wave of globalization. ${ }^{2}$ A renewed, if somewhat belated, interest in this earlier period is broadly welcome. However, the historical parallel has given rise to a distinct perspective, which has gained increasing acceptance among policy makers and academics, seeing in the current period a return to the earlier period of globalization:

Then as now, capital transactions were relatively free and capital flows were dominated by securities markets. Hence, the current regime can be seen as a return to the liberal international order that existed before 1914 after a long diversion brought about by the disruptions of two world wars (IMF, 1994, p. 129).

In an important article in the recent 25th anniversary edition of the Brookings Papers, Jeffrey Sachs and Andrew Warner have provided an extended defence of this argument. Their discussion of the period 1870-1913 can be synthesized into four stylized facts, which will serve as the basis for our discussion of globalization myths (Sachs and Warner, 1995, pp. 5-11). First, from the 1860s onwards, low tariff barriers and technological breakthroughs in long-distance transportation and communications stimulated export growth and rising trade shares. Differences in resource endowments ensured that this trade had a strong North-South dimension as developing countries in Latin America, much of Asia and parts of Africa specialized in raw material exports and imported manufactured goods. Second, the adoption of appropriate legal institutions in a number of countries along with the spread of the gold standard, convertible currencies and the assumption of financial leadership by Great Britain stimulated large and relatively stable international capital flows. Because these capital flows were driven by the search for higher profit opportunities in emerging growth markets they strongly complemented trade flows. Third, the spread of capitalist institutions and free trade and capital flows generated a new growth momentum encompassing the whole world economy. Industrialization spread rapidly beyond the core North Atlantic economies to include the emerging markets of Continental Europe and Japan. But the

\footnotetext{
See Henderson, 1992; Cable, 1995; World Bank, 1995; Krugman, 1995. There have been two established approaches among historians to this earlier epoch, both of which have influenced current thinking. The first, which might be dubbed "Keynesian" because one of its earliest and most eloquent statements can be found in the Economic Consequences of the Peace, looks back at this period from the perspective of the instability of the inter-war years. A second more "institutional" perspective has long been aware of the pace of economic integration before the First World War in association with the workings of the international gold standard.
} 
period also saw the take-off of many developing regions, including the raw material exporters in Latin America, Asia and Africa. Moreover, this was a period of convergence as poorer economies grew faster than the richer economies in large part thanks to rapid export growth. Fourthly, the end of this global age of integration was sudden, unexpected and the result of exogenous political and military shocks. As a result of the first World war, socialist revolution and a new statist zeitgeist the global capitalist system was laid waste for over half a century.

Sachs and Warner (1995) make a direct parallel between these features of 19th century globalization and developments in the late 20th century anticipating similar results in terms of broad economic trends in the world economy:

The world economy at the end of the 20th century looks much like the world economy at the end of the 19th century. A global capitalist system is taking shape, drawing almost all regions of the world into arrangements of open trade and harmonized institutions. As in the 19th century, this new round of globalization promises to lead to economic convergence for the countries that join the system (Sachs and Warner, 1995, p. 61).

Moreover, like the previous globalization period, Sachs and Warner argue that this promise of a global capitalist system in terms of growth and convergence will depend upon appropriate policy choices. In particular, all governments but particularly those in the developing world must commit themselves to a rapid and comprehensive agenda of liberalization in areas of trade, capital flows and foreign direct investment. Much of their paper attempts to substantiate this strong globalization thesis for the contemporary period. But is the parallel with the process of global economic integration before the First World War an accurate one and does it support their policy advice?

\section{TRENDS IN INTERNATIONAL PRODUCTION AND FINANCE BEFORE 1914}

The period 1870-1913 certainly witnessed a rapid expansion in international trade. The growth of trade averaged 3.5 per cent per annum during this period compared with output growth of 2.7 per cent (Mitchie and Kitson, 1995, table 1.1). ${ }^{3}$ As a result, the share of trade in output (or openness) rose steadily reaching a high point in 1913 which was not surpassed until the 1970s (table 1). There was, of course, considerable country variation around this trend, with a group of smaller "super-trading economies", such as Belgium, the Netherlands and Switzerland, having a much higher degree of

\footnotetext{
3 Angus Maddison (1989) estimates that the annual growth of trade was slightly higher (3.9 per cent) and output growth slightly lower (2.5 per cent).
} 
openness than larger European economies, such as France and Italy. ${ }^{4}$ There was also variation among countries in their peaks of openness; the United States (and Canada) reached its peak around 1900, falling back slightly in the years before the First World War, while Japan did not reach its peak until 1929 - a peak it has still not surpassed. This variation across countries and over time already points to inconsistencies in the idea of a continuous and common process of trade-led integration during this period.

Table 1

Merchandise exports as a percentage of GDP, 1870-1992

(Three year annual average, except for 1950)

\begin{tabular}{|l|c|c|c|c|}
\hline & $\begin{array}{c}\text { Western } \\
\text { developed } \\
\text { countries }^{\mathrm{a}}\end{array}$ & United States & Western Europe & Japan \\
\hline 1870 & $\ldots$ & 5.4 & 13.6 & $\ldots$ \\
\hline 1890 & 11.7 & 6.7 & 14.9 & 5.1 \\
\hline 1913 & 12.9 & 6.4 & 18.3 & 12.5 \\
\hline 1929 & 9.8 & 5.0 & 14.5 & 13.6 \\
\hline 1938 & 6.2 & 3.7 & 7.1 & 13.0 \\
\hline 1950 & 7.8 & 3.8 & 13.4 & 6.8 \\
\hline 1970 & 10.2 & 4.0 & 17.4 & 9.7 \\
\hline 1992 & 14.3 & 7.5 & 21.7 & 8.8 \\
\hline
\end{tabular}

Source: $\quad$ Bairoch (1996a), tables 1 and 4, with additional data for 1870.

a For reasons of statistical consistency, the Western developed countries include the following regions and countries: all Western Europe excluding Yugoslavia, the United States and Canada, Australia, New Zealand and Japan.

Although trade was clearly an important feature of the late 19th century world economy, some of the most striking myths - which have been revived in the contemporary discussion of globalization -concern the forces driving international trade. Of these, undoubtedly the most prominent and persistent is the idea that this was an era of trade liberalization.

In the first half of the 19th century free trade, both in theory and in practice, was a British preoccupation. Declining trade barriers did become a more general trend beginning around 1860 with the Anglo-French trade treaty, followed by treaties between France and many other countries, which led

\footnotetext{
4 This small group of exported-oriented newly industrializing economies, has some parallels with today's newly industrializing economies, particularly in East Asia.
} 
to tariff disarmament in Continental Europe, mostly as a result of the inclusion of a most-favourednation clause (Kenwood and Lougheed, 1994, pp. 64-66). However, this interlude lasted less than two decades and was confined to Europe (Bairoch, 1989). Coinciding with the start of European liberalization, and accelerating after the North's victory in the Civil War, the United States economy began its period of import substitution industrialization behind rising tariff barriers; the tariff in force from 1866 to 1883 provided for import duties averaging 45 per cent for manufactured goods (the lowest rates of duty were about 25 per cent and the highest about 60 per cent). Given the growing weight of the United States economy in the world economy during the forty years before the First World War, excluding its experience from the lessons of global integration is a rather significant oversight which has helped perpetuate the mistaken notion of an "Anglo Saxon" model of capitalist development (KozulWright, 1995b).

During the three decades up to the First World War rising protection was the common trend in the developed world, largely as a result - in Continental Europe at least - of a coalition between agrarian interests and the representatives of fledgling industry who found common ground in higher tariffs as a response to the inflow of cheap grain from the United States and Russia and the long depression of 1870s (Hobsbawm, 1994b, pp. 38-40). Although tariffs rose only gradually up to the early 1890s, because most new duties were based on specific quantities and were not ad valorem, and because this was a period of falling prices, the significance of tariff protection was greater than the nominal figure might otherwise suggest. From the early 1890s protectionism became a much more pronounced trend and by 1913 all the large countries had adopted a protective stance (table 2). ${ }^{5}$ Even some of the smaller European economies, such as Sweden, made a decisive move in this direction. And after regaining its autonomy over tariff policy in the late 1890s, Japan also sought tariff protection for its infant industries.

If by 1913 trade policy in the developed world is best described as islands of liberalism surrounded by a sea of protectionism, the developing world might best be characterized as an ocean of liberalism with islands of protectionism. In many cases, openness to trade was the direct result of colonial rule, where the general principle consisted of free access to all the products of the colonial

\footnotetext{
$5 \quad$ It should be noted that for the smaller and more open economies average tariff figures hide the fact that specific industries received much higher protection.
} 
Table 2

Incidence of protection, 1875 and 1913

\begin{tabular}{|l|c|c|c|}
\hline \multirow{2}{*}{} & \multicolumn{2}{|c|}{$\begin{array}{c}\text { Average levels of duties on } \\
\text { manufactured goods }\end{array}$} & All products \\
\cline { 2 - 4 } & 1875 & 1913 & 1913 \\
\hline Austria-Hungary & $15-20$ & $18-20$ & $18-23$ \\
\hline Belgium & $9-10$ & 9 & $6-14$ \\
\hline Denmark & $15-20$ & 14 & 9 \\
\hline France & $12-15$ & $20-21$ & $18-24$ \\
\hline Germany & $4-6$ & 13 & $12-17$ \\
\hline Italy & $8-10$ & $18-20$ & $17-25$ \\
\hline Russia & $15-20$ & 84 & 73 \\
\hline Spain & $15-20$ & $34-41$ & 37 \\
\hline Sweden & $3-5$ & $20-25$ & $16-28$ \\
\hline Switzerland & $4-6$ & $8-9$ & $7-11$ \\
\hline Netherlands & $3-5$ & 4 & 3 \\
\hline The United Kingdom & 0 & 0 & 0 \\
\hline The United States & $40-50$ & $44^{\mathrm{a}}$ & $33^{\mathrm{b}}$ \\
\hline
\end{tabular}

Source: $\quad$ Bairoch (1993), tables 2.2, 2.3 and 3.2; and Bairoch (1989), pp. 144.

a After 9 October 1913, 25 per cent.

b After 9 October 1913, 16 per cent.

power. ${ }^{6}$ However, the fact that tariffs had played an important role in the rejection by the United States of British rule was an important factor in Britain's early decision to grant a large measure of tariff independence to what were later to become the self-governing colonies (Canada, Australia and New Zealand). While all these countries, but particularly Canada, used this independence to protect infant industry they all retained preferences for British goods. In the nominally independent States of Latin America and East Asia, Western pressure had imposed on most of them treaties (mainly with Britain) in the first half of the 19th century which entailed the elimination of customs and duties. Generally, it was the " 5 per cent rule" that applied, that is, a tariff regulation under which no duty could rise above 5 per cent of the import value of the goods. All these treaties opened up markets to British and European 
manufactured goods. However, between 1870-90 a number of Latin American countries, notably Brazil, turned to more protectionist policies as a means to promote industrialization. ${ }^{7}$

If the idea that liberalization was an important driving force behind rising trade between 1870 and 1913 is largely a myth, is it still the case that resource endowments were the key to trade flows and that the geographical composition of trade during this period, to a large extent, was dominated by a NorthSouth pattern? Perhaps the first thing to note is the degree of stability in trade shares throughout this period. World trade was dominated by intra-European trade and Europe's trade with overseas areas; Europe accounted for 66.9 per cent of total trade at the beginning of this period and 62 per cent in 1913 with a corresponding small rise in the North American share (Kenwood and Lougheed, 1994, p. 80-81). Still, the fact that trade in primary commodities continued to dominate world trade and actually grew slightly faster than trade in manufacturing goods over this period might suggest that North-South trade dominated; the share of primary products in world trade peaked in the late 1890s when it accounted for 68 per cent before falling back slightly to 62.5 per cent in 1913 (Kenwood and Lougheed, 1994, p. 83). Moreover, if the United Kingdom - the leading trading nation throughout this period - is taken as exemplar, then the dominance of North-South trade would indeed appear to be an appropriate description (Krugman, 1995); the United Kingdom exported manufactures to and imported primary commodities from the developing world. But as table 3 shows, the United Kingdom was in important respects, the exception rather than the rule. Other countries in the North traded much more intensively with each other, including in manufactured goods; exports of manufactures to other industrial economies as a share of total manufacturing exports was less than one-third in the United Kingdom in 1913 but any where from one half to two-thirds in the other industrializing economies. Thus, in 1913 close to forty per cent of total world trade was taking place between European economies, and broadening the perspective to all industrial economies the figure was around 60 per cent (Maizels, 1963) Much of this intra-North trade was, of course, trade in primary products. However, it is important to remember that many of the leading primary producers at this time were not low income economies and it would seem that international trade in the period before the First World War was, to a large extent, connecting the richest parts of the world economy.

The discovery of intra-industry trade in the post-second World War period has often been taken as an indication of a major change in the international division of labour. In fact industrial interdependence has been rising since the mid 19th century. Already by 1899 manufacturing trade was dominated by trade among industrial countries, accounting for 54 per cent of world trade in manufactures, and although the growth of this intra-North trade was slightly slower than exports to the rest of the world between 1899-1913 - an annual rate of 3.7 compared to 4.1 per cent - this was

\footnotetext{
The first Brazilian tariff of 1879 was the result of a trade mission to Europe to study trade liberalization, which came back converted to infant-industry protection (Bandeira de Mello, 1935).
} 
Table 3

Commodity and geographical composition of exports, 1913

(Percentage shares)

\begin{tabular}{|l|c|c|c|c|}
\hline & $\begin{array}{c}\text { Share of } \\
\text { world exports }\end{array}$ & $\begin{array}{c}\text { Trade with } \\
\text { the North }\end{array}$ & $\begin{array}{c}\text { Exports of } \\
\text { manufactures as } \\
\text { share of total } \\
\text { exports }\end{array}$ & $\begin{array}{c}\text { Exports to other } \\
\text { industrial } \\
\text { economies as share } \\
\text { of total } \\
\text { manufacturing } \\
\text { exports }\end{array}$ \\
\hline United Kingdom & 22.8 & 37.9 & 76.6 & 31.8 \\
\hline France & 12.1 & 68.2 & 57.9 & 63.8 \\
\hline Germany & 21.4 & 53.4 & 71.7 & 53.5 \\
\hline $\begin{array}{l}\text { Other Western } \\
\text { European }\end{array}$ & 15.0 & 70.3 & 49.4 & 62 \\
\hline United States & 22.1 & 74.5 & 34.1 & 63.2 \\
\hline
\end{tabular}

Source: $\quad$ Maizels (1963), table A1 and A3.

still the case in 1913 (Maizels, 1963, p. 89). Although there is little direct evidence, it seems unlikely that intra-industry trade was absent from 19th century globalization (Rayment, 1983). It is also almost certainly the case that, in light of the large stock of foreign direct investment (FDI) accumulated during this period, much of the trade was intra-firm trade (Wilkins, 1995). All this goes a long way to suggest that confining the pressures behind international trade in this earlier period to a given distribution of resource endowments hides a more complex and more dynamic process.

Although absent from Sachs and Warner's account of late 19th century globalization, the introduction of intra-firm and intra-industry trade reminds us that the internationalization of production was an important feature of developments in the world economy. It is thus a myth that international production is a distinct feature of the current period of globalization. Foreign direct investment was growing rapidly during this earlier period, accounting for as much as one-third of overseas investment. Indeed, our own estimate suggests that the stock of FDI reached over 9 per cent of world output in 1913, a figure which had not been surpassed in the early 1990s. 
Much of the FDI in this period was seeking natural resources in developing countries, in which respect it was a stimulus to trade. ${ }^{8}$ Perhaps a little over a half of FDI went directly to the primary sector during this period (Dunning, 1984, p. 89). However, it would be misleading to restrict the discussion of the role of transnational corporations (TNCs) to developments in this sector. In some important host countries, such as Argentina and Brazil, there was considerable FDI in railways and utilities - although in many cases this was related to FDI in the primary sector - and in other countries, including Russia, which was the second largest host in this period behind the United States, there was considerable FDI into manufacturing, including chemicals, metal fabricating, textiles and metal refining. Outward FDI from Germany and France went into manufacturing in other European countries, especially Russia, and United States investments in Canada were also in manufacturing. It seems likely that the growing role of FDI in this sector was as a substitute for trade in response to rising tariff barriers (Kenwood and Lougheed, 1994, p. 35).

During this era of global integration, there is little doubting that TNCs were having an impact on economic integration and development. Moreover, the close links between trade and FDI whether as complementary aspects of an integrated division of labour organized within the firm or as an alternative means of gaining market access, suggest that the pressures shaping international production were often of a dynamic nature closely related to the growth of large firms whose expansion abroad aimed to strengthen profit opportunities in an increasingly competitive environment.

Although the importance of FDI in 19th century globalization has often been ignored or downplayed, the role of international finance has received extensive discussion. Like the current period, this emphasis reflects the real dominance of finance in the globalization process; between 1870-1913, the growth of foreign portfolio investment exceeded the growth of trade, FDI and output. By 1913, the volume of international capital flows had reached 5 per cent of the GNP of the capital exporting countries (Bairoch, 1976, p. 99), and the available evidence points to considerable integration of international financial markets (Zevin, 1988). Western Europe was the major source of supply of foreign capital throughout this period. In 1874, the combined total of Britain, Germany and France amounted to some $\$ 6$ billion. By 1914 this figure had risen to $\$ 33$ billion out of a total of $\$ 44$ billion. Among these leading financial powers, Britain was, unquestionably, the single largest overseas investor during this period; between 1870 and 1914 the average annual outflow of capital was around 4 per cent of national income, and actually reached a staggering 9 per cent at the end of this period.

But like many of the myths surrounding international trade, those surrounding international finance stem from an excessive focus on Britain's role in the world economy. It is undoubtedly true that the gold standard made possible increased capital flows and that the role of sterling and the dense 
network of institutions which made up the London capital markets were of paramount importance to the efficient workings of this international monetary system. However, then, as today, the links between finance and economic development were complex. According to conventional wisdom, a fully globalized capital market should sever the links between national savings and investment, and reallocate global savings from the capital-rich to the capital-scarce countries, strengthening the development prospects of poorer countries. It was certainly the case that between 1870 and 1914 the share of British foreign investments going to Europe and the United States halved, from 52 per cent to 26 per cent of the total, while the share of Latin America and the British Dominions rose from 23 per cent to 55 per cent of the total (Kenwood and Lougheed, 1994, p. 30). However, taking the world as a whole, while half of all lending went to Asia, Latin America and Oceania-Africa, half went to other advanced countries, and one-quarter was to North America alone, by then the wealthiest region of the world economy (table 4). Moreover, the large capital flows to Latin America were very unevenly distributed, the majority directed to the wealthiest parts of the continent; during the 1880s just two nations - Argentina and Uruguay - were responsible for over 60 per cent (in value terms) of all loans negotiated in the region (Marichal, 1989, p. 127).

Table 4

Main international lenders and borrowers: 1913

(Percentage of total)

\begin{tabular}{|l|c|c|l|c|c|}
\hline & $\begin{array}{c}\text { Total } \\
\text { overseas } \\
\text { investment }\end{array}$ & FDI & \multicolumn{1}{|c|}{ Region } & $\begin{array}{c}\text { Total } \\
\text { overseas } \\
\text { investment }\end{array}$ & FDI \\
\hline Britain & 41 & 45.5 & Europe & 27 & 17.7 \\
\hline France & 20 & 12.2 & Latin America & 19 & 32.7 \\
\hline Germany & 13 & 10.5 & North America & 24 & 16 \\
\hline $\begin{array}{l}\text { United } \\
\text { States }\end{array}$ & 8 & 18.5 & Asia & 14 & 20.9 \\
\hline Others & 18 & 13.3 & Africa-Oceania & 16 & 12.6 \\
\hline
\end{tabular}

Source: Kregel (1994), p. 23; Dunning (1984).

Another myth is that capital flows were dominated by the market sentiment of private investors during this period. It certainly not the case that, as suggested in the earlier quote from the IMF, securities 
markets were dominant. Rather bond issues dominated other debt instruments (notably equities) and the floatation of new issues dominated trading of second-hand debt. Although a fairly significant proportion of these flows did bring together developing country issuers of long-term liabilities with private individuals and financial institutions in developed countries seeking long-term investments (Kregel, 1994), the bulk of foreign lending went into railways, utilities and public works and one of the most important features of the international capital market at this time was the influence of government borrowing; according to Bloomfield (1968, p. 4), in 1914 as much as 70 per cent of outstanding British and French long-term foreign investments consisted of government and railway bonds.

Finally, it is worth emphasising that not all countries actually adhered to the gold standard throughout this period. The majority of (independent) countries were late arrivals, maintained a rather lose allegiance or never joined (Panic, 1992, pp. 32-33). Moreover, those countries which did remain committed to the gold standard were not subject to autonomous pressures whereby employment and income were automatically reduced in order to eliminate deficits on their current account balances (Panic, 1992, ch. 3), thereby sacrificing short-term economic welfare for the financial discipline necessary for long-term stability and growth.

The discussion of globalization before the First World War appears to be a collection of myths and realities. Undoubtedly, international production and financial activities were evolving rapidly. But their development was very uneven both geographically and by sector. In particular, international capital flows, like international trade flows, during this period were highly concentrated, with a very high proportion absorbed by those countries which were already the wealthiest and most dynamic in the world economy. At the same time, the most dynamic sector in the world economy, industry, was the least globalized. Moreover, the idea that national States were impotent in the face of international pressures paints a particularly misleading picture of developments during this period.

Before linking the trends in international production and finance to other aspects of economic development before the First World War, it is worth making a brief comparison with the inter-war period, a comparison which has been a source of a number of globalization myths. Contrary to much conventional wisdom, the inter-war period was not one of stagnation but contained spurts of rapid growth. Indeed, the 1920s grew considerably faster than any previous decade, and taking a longer perspective there was, in fact, very little difference in the annual growth rate in the globalization era and the period 1913-1950 (see chapter IV below). It is also a myth that globalization tendencies were absent from the inter-war period. Although the average annual growth of trade in the 1920s was slower than in the previous epoch it was actually faster than in the period 1870-1890 and trade grew very rapidly between 1924-1929. Indeed, by 1929 the share of trade in world output was close to its 1913 level, and actually peaked in some countries, most notably Japan. Also between 1914 and 1938, the stock of FDI rose significantly, almost doubling from $\$ 14.3$ billion to $\$ 26.4$ billion. There was particularly rapid 
growth of outward investment from the United States which included new locations in the developing world to access oil, minerals, and rubber as well as public utilities (Dunning, 1984, pp. 91-93).

Without elaborating further on these trends, they do go some way to exposing the myth that the disintegration of the global economy can be explained simply by irrational political factors unleashed by the First World War and its aftermath. At the very least, the political economy of the inter-war period involved a complex intertwining of domestic and international economic forces.

\section{INDUSTRIALIZATION AND THE NEW INTERNATIONAL DIVISION OF LABOUR}

The current era of globalization has coincided with, and in important respects reinforced, a downgrading of industry's role in economic growth and development. ${ }^{9}$ By contrast, the dynamic role of industrial development in the earlier period of globalization is not in doubt. During the period 18701913, manufacturing output rose fourfold at an annual growth rate of 3.5 per cent (League of Nations, 1945, table 1), more rapidly than world trade and trade in manufactures and certainly more rapidly than FDI in manufacturing. Rapid industrial development, moreover, was closely associated with a burst of technological progress, a series of profound socio-economic change in the organization of production and work, and was instrumental in giving shape to the modern political landscape.

When the rapid growth economies of this period are examined more closely, there is little doubting that industrial development was the real engine of growth during this period; the 5.1 per cent average annual growth of manufacturing output in the United States between 1871/75-1881/85 which was unprecedented historically, was surpassed during the following decade by a number of countries, notably Sweden and Finland (8.2 per cent and 8.5 per cent respectively), and which were in turn surpassed over the next decade by Japan whose manufacturing sector grew at annual rate of 9.0 per cent (League of Nations, 1945, table 8). Consequently, on some measures the most dynamic part of the world economy was becoming less globalized during this period.

As important as this rapid growth of world manufacturing output was, just as significant was its changing geographical composition (table 5). During this period, Britain ceased to be the only truly industrial power and in 1913 both the United States and Germany were contributing a larger share of world output. Just as striking, while in 1870 no country had achieved a per capita industrialization level

Deindustrialization is the source of a number of contemporary globalization myths. On the one hand, a post-industrial society thesis has fused with globalization to suggest that manufacturing will disappear from the North as it becomes a specialized service producer, importing manufactures from the South (Brown and Julius, 1994). On the other hand, ideas of a new international division of labour have linked deindustrialization in the North to the growth of low-skill manufactured exports from the South (Wood, 1994), raising the prospect of immiserization of large sections of the Northern labour force. See UNCTAD (1995) for a critique of both these globalization myths. 
half that of the lead economy (the United Kingdom), by 1913 five economies (the United Kingdom, Belgium, Switzerland, Germany and Sweden), had a level more than half that of the United States, by then the lead industrial economy. Still, at the end of this period of globalization, the core of world industry comprised a very small group of countries and even among these it would be misleading to give too much emphasis to the process of convergence. In 1860 the three leading industrial nations produced a little over a third of total output, by 1913 their share was a little under two-thirds (of a much larger total). Industrial development in much of Southern and Eastern Europe was weak and erratic in comparison to the successful catch-up economies. This was the case for France, Italy, Russia and Austro-Hungary, each of which had pockets of advanced industrial development by 1913, but were unable to reach and sustain the very rapid rates of growth of the other newly industrializing economies. Thus, while the relative decline of Britain as the economic and industrial hegemon was inevitable, there was nothing spontaneous or predictable about the path of late industrialization.

Table 5

Percentage distribution of the world's manufacturing production

\begin{tabular}{|l|c|c|c|c|c|c|c|}
\hline & $\begin{array}{c}\text { United } \\
\text { States }\end{array}$ & $\begin{array}{c}\text { United } \\
\text { Kingdom }\end{array}$ & Germany & France & Russia & $\begin{array}{c}\text { Other } \\
\text { developed }\end{array}$ & Other \\
\hline 1830 & 2.4 & 9.5 & 3.5 & 5.2 & 5.6 & 13.3 & 60.5 \\
\hline 1860 & 7.2 & 19.9 & 4.9 & 7.9 & 7.8 & 15.7 & 36.6 \\
\hline 1913 & 32.0 & 13.6 & 14.8 & 6.1 & 8.2 & 17.8 & 7.5 \\
\hline
\end{tabular}

Source: Bairoch (1982).

This uneven pattern of industrial development among the more advanced economies of Europe and North America is not explained by differences in resource endowments, including human capital, although this was certainly a factor in some cases (Cameron, 1985; O'Rourke and Williamson, 1995). Rather, it was probably a reflection of the extent to which some late industrializing countries were able to bridge an institutional hiatus with the lead industrial economies and begin a process of catching-up through high rates of investment, technological progress and rapid productivity growth. In practice, this meant establishing a series of complementary institutional structures necessary to accelerate investment, including a secure system of property rights but also the establishment of an effective financial system with close links to the industrial sector (Studart, 1995, pp. 68-76). It also included profound changes at the enterprise level both in the scale of production units and in managerial and entrepreneurial 
capabilities, as well as the creation of new linkages within and between industrial sectors, associated with the dynamic complementarities and externalities associated with technological progress. Moreover, as Alexander Gershenkron suggested a long time ago, all the successful late industrializers in this era were characterized by reforms to their State structures which helped encourage accumulation and technological progress, through infant industry protection and other (incipient) forms of industrial policy. ${ }^{10}$

But if unevenness among the more advanced countries was an important feature of industrialization in the era of globalization, just as striking was the polarization of industrial activity between the North and South. Deindustrialization in developing countries predated the era of global integration; both in absolute terms and as a share of world manufacturing output, the position of the developing world declined sharply between 1830 and 1860 (table 5). But this process continued, and indeed, accelerated, during much of the period of global integration. Between 1860 and 1913, the developing country share of world manufacturing production declined from over one-third to under a tenth (Bairoch, 1982). There seems little doubt that deindustrialization in the South was the result of a massive inflow of European manufactured imports. This was particularly true of the textile and clothing industries, where free trade exposed the local artisanal and craft producers to the destructive competitive gale of more capital intensive, high productivity Northern producers. The destruction of the Indian textile industry provides the most familiar example of this process, but similar cases can be found across Latin America and the Middle East (Batou, 1990). The absolute destruction of industrial capacity in the South appears to have been reversed beginning around 1900 and was, in some instances followed by quite rapid bursts of growth, often with advanced industrial techniques linked to FDI. However, in no case was the basis for sustainable industrial growth laid in the developing world in this latter period.

While late industrialization certainly opened up a sustainable growth path for those States able to intervene effectively to alter their position in the emerging international division of labour, the question still remains whether it was necessary to industrialize to benefit from globalization. An increasingly popular myth from this earlier period is that, in line with comparative advantage, the export of primary products provided the best growth path for many parts of the world economy. ${ }^{11}$

There is, of course, an element of truth behind this myth; in 1913, five exporters of primary products were among the world's richest countries (table 6). Indeed, the United States which had become the lead economy in the world had an export profile dominated by primary products. The other

\footnotetext{
10 Gershenkron's thesis is usually illustrated with reference to German, Russian and Japanese development. But it is equally true of some of the most successful late industrializers, for example, Sweden (see Chang and Kozul-Wright, 1994) and the United States (Kozul-Wright, 1995b).

11 In today's globalizing world, a number of developing countries, such as Chile, are placing considerable faith in this rediscovery of primary exports (see World Bank, 1995). There is, of course, an opposing myth with its roots also in the pre-1913 era, which sees such exports as the basis of economic dependency and stagnation. For a critique, see Bairoch (1993).
} 
wealthy primary exporters included Australia, Canada, Denmark and New Zealand. Argentina (and Uruguay), whose GNP per capita was the average for developed countries at the beginning of the globalization era, should also be included among this group of rich primary exporters, particularly if it is recognized that large parts of the country had a per capita income which far exceeded the average (Marichal, 1989, p. 145). It is also the case, that the average annual growth rate of these six economies between 1870-1913 was, with the exception of New Zealand, significantly higher than the average for other developed countries (table 6). With the exception of the mineral-rich North American economies, the place of these economies in the international division of labour was determined by the export of agricultural products.

Table 6

Primary producers in the new international division of labour, 1870 and 1913

\begin{tabular}{|l|c|c|c|c|c|}
\hline \multirow{2}{*}{} & \multicolumn{2}{|c|}{ GNP per capita $^{\mathrm{a}}$} & \multicolumn{2}{c|}{$\begin{array}{c}\text { Average annual } \\
\text { growth, 1870- } \\
1913\end{array}$} & \multicolumn{2}{c|}{$\begin{array}{c}\text { Primary exports } \\
\text { as a share of total } \\
\text { exports, } 1913\end{array}$} \\
\cline { 2 - 6 } & 1870 & 1913 & 2.0 & $62^{\mathrm{b}}$ & $75^{\mathrm{c}}$ \\
\hline United States & 580 & 1358 & 2.4 & 97 & 97 \\
\hline Argentina & 360 & 1010 & 2.0 & 88 & 97 \\
\hline Australia & 667 & 1096 & 2.0 & 80 & 88 \\
\hline Canada & 470 & 1112 & 2.1 & 100 & 100 \\
\hline Denmark & 365 & 883 & 1.1 & 100 & 100 \\
\hline New Zealand & 480 & 756 & 1.4 & 27 & 33 \\
\hline $\begin{array}{l}\text { Total } \\
\text { developed } \\
\text { countries }\end{array}$ & 360 & 662 & & & \\
\hline
\end{tabular}

Source: $\quad$ Bairoch (1996b) and Yates (1959) - data for Argentina and New Zealand GNP are preliminary).

$\boldsymbol{a} \quad$ In 1960 US dollars and prices. $\boldsymbol{b}$ Excluding metals. $\boldsymbol{c}$ Including metals.

However, a closer examination of the experience of these economies casts doubt on the idea that primary sector led growth provided an optimal strategy for much of the world economy. In the first place, these countries were relatively wealthy before the start of the globalization era; these were the lead economies of an essentially pre-industrial world (table 6). Second, and in striking contrast to the current period of globalization, primary producers, with the exception of sugar producers, experienced a 
particularly favourable shift in terms of trade; between the 1870s and late 1920s, the terms of trade for primary products relative to manufactured goods improved by between 10 and 25 per cent. ${ }^{12}$

But even ignoring these favourable circumstances, the best proof of the limits of specializing in primary products and the more dynamic impact of industrialization on economic growth and development is found in the fact that all countries that successfully established an industrial base have become rich, as opposed to the successful exporters of primary goods which, with the exception of North America, have seen GNP per capita fall to or below the average for developed market economies over the intervening three-quarters of a century. Thus, New Zealand, which was the sixth or seventh richest country in the world around 1880, had by 1990 declined to around twentieth position and the relative decline of Argentina was even more pronounced.

Thus, from this brief review of the evidence, we can conclude that while specializing in exports of primary goods was consistent with a high level of income, maintaining that level and pushing the economy on to a new dynamic growth path required not only that the export sector increase its productivity but that there was a structural shift in the pattern of economic activity towards industry. Eric Hobsbawm's observation that even as the favoured white settler colonies became prosperous through exporting primary resources, the "cage of international specialization" was restricting their future growth potential, from which only a small number escaped (Hobsbawm, 1994a, p. 64) seems even more appropriate for those countries which lacked the advantages of this small group of economies.

\section{GROWTH AND CONVERGENCE IN THE WORLD ECONOMY BEFORE 1913}

The contemporary significance of the globalization debate does not lie in reporting broad trends in the world economy, but in the inferences drawn from these trends for growth and development prospects, and the accompanying policy advice. As Sachs and Warner make clear, globalization is expected to release a new growth dynamic in the world economy. Although it is probably no accident that the current debate on globalization has coincided with a revival of Hecksher-Ohlin trade theory, a mixture of static and dynamic advantages linked to greater openness through such channels as increased competitiveness and economic efficiency, greater specialization and learning economies, and FDI and technological upgrading, underpin this expectation (Sachs and Warner, 1995, p. 3; O'Rourke and Williamson, 1995). Perhaps more importantly for the policy debate, these channels are expected to have their greatest impact on the growth potential of developing countries and the single greatest obstacle to 
rapid growth and convergence in the world economy lies in States adopting a national policy focus which establishes a path towards marginalization and economic stagnation.

An immediate problem with this argument is that the world economy has been on a visibly slower growth path over the past two decades and that most of the available evidence points to divergence, not convergence among countries. ${ }^{13}$ What then are the lessons on the links between globalization, growth and convergence from the 19th and early 20th centuries?

In the first place, it should be noted that although there was an acceleration of growth in the period 1870-1913, it was not impressive by the standards established during the Golden Age of capitalism after 1945. Indeed, the average growth rate of 1.4 per cent per annum for the world economy between 1890 and 1913 - a rate faster than that achieved in the previous two decades - was little different than that achieved in the period 1920-1950. Equally telling, although the period from 1890-1913 did see a jump in growth rates in the developing world, the gap with the developed countries was not closed (table 7). There was consequently, no convergence across the world economy in this period and if anything, much like the current period, the 19th-century episode of globalization was marked by divergence.

Mica Panic's description of this earlier globalization era as one divided into distinct growth clubs seems an appropriate one (Panic, 1992, pp. 32-37). A small group of rapidly industrializing economies did exhibit convergence, and because it included the United States represented a significant part of the world economy. These same economies were also the core of the gold standard and their rapid growth ensured that they benefited most from international flows of capital. A small group of settler economies maintained a high level of income through the export of food and raw materials to the rapidly industrializing economies but, in most cases, these were unable to sustain high growth rates. Finally, a rather more diverse group of outsiders shared a tenuous position in the new international division of labour. Some did begin to industrialize and exhibited very rapid productivity growth towards the end of this period, although this was not always sustainable. But most were unable to establish, or in those countries under colonial control were prevented from attempting, an industrialization path.

13 See Milberg, 1995; Elmslie and Milberg (forthcoming). The reasons why some developing countries - notably the East Asian newly industrializing economies - have successfully adapted to the pressures of globalization, are the source of considerable disagreement among economists (see World Bank, 1994; UNCTAD, 1994). However, greater openness to FDI and TNC activity is not what distinguishes them from their less successful counterparts in the developing world (Chang, 1995). 
Table 7

Trends in economic growth, 1830-1990

(Annual growth rates of the volume of GNP per capita, based on three-year averages)

\begin{tabular}{|l|c|c|c|}
\hline & Developed countries & Developing countries & World \\
\hline $1830-1870$ & 0.6 & -0.2 & 0.1 \\
\hline $1870-1890$ & 1.0 & 0.1 & 0.7 \\
\hline $1890-1913$ & 1.7 & 0.6 & 1.4 \\
\hline $1913-1920$ & -1.3 & 0.2 & -0.8 \\
\hline $1920-1929$ & 3.1 & 0.1 & 2.4 \\
\hline $1929-1950$ & 1.3 & 0.4 & 0.8 \\
\hline $1950-1970$ & 4.0 & 1.7 & 3.0 \\
\hline $1970-1990$ & 2.2 & 0.9 & 1.5 \\
\hline
\end{tabular}

Source: Bairoch (1993.)

Bearing in mind this diversity, is it possible to identify the underlying causes of economic growth in the half century before the First World War? From our earlier discussion, it should be apparent that trade liberalization was not a stimulus to growth; rapid export growth in this period occurred against a tide of rising protection, at least in the newly industrializing parts of the world. Moreover, it should be recalled that trade flows continued to be dominated by primary products and the most dynamic sector of the world economy at this time, industry, was not participating to the same extent in the globalization process. Furthermore, although it is undoubtedly true that rapid export growth in a group of small industrializing economies was an important stimulus to growth, for most countries the causal links between trade and economic growth are more difficult to make. ${ }^{14}$

However, a closer inspection of the 19th century episode of globalization does provide some evidence to suggest that economic growth leads to international trade and not vice versa. Thus, the period of trade openness between 1860-1879 coincided with slower growth of both output and exports. Just as significantly, the subsequent move towards protectionism coincided with a period both of more rapid economic growth and also trade; during the 20 years following the reintroduction of protectionist policies the annual growth of output increased by more than 100 per cent and the volume of exports grew by more than 35 per cent. Looking at individual country experiences (table 8), it is the case that

14 For a review of the contemporary literature on the links between trade and growth which also reaches this agnostic conclusion, see Edwards (1993). 
in all countries (except Italy) that the introduction of protectionist measures coincided with a distinct acceleration of economic growth during the first ten years following a change in policy. In the next ten years, during which protectionist measures were strengthened, there was usually a further acceleration in economic growth. As far as foreign trade is concerned, an almost universal slowing of expansion is noticeable in the first ten years after the abandonment of free trade, but in the second ten years, the rate of growth in the volume of exports in nearly all the protectionist countries was faster than it had been in the ten years prior to the adoption of protectionist measures.

Given the close association between globalization and FDI in the current period, and in light of our earlier conclusion that TNCs were a more prominent feature of the pre-First World War international economic landscape than has been recognized, it is important to ask whether TNCs were an engine of growth in this period. There is little doubt that TNCs were linked to areas of quite rapid growth in some developing countries, and both for primary sector and industrial activities, where they could introduce rapid technological and organizational change at the enterprise level which would have evolved more slowly, or not at all, from purely domestic sources. However, from a national perspective, given the concentration of FDI in the primary sector and related services, the engine of growth story is much less convincing. This is not only because of the particular sectoral bias of FDI flows but equally because the very uneven pattern of FDI flows suggests that they were as much a response to, as a cause of, growth opportunities.

Thus the United States and Canada, both wealthy economies, were among the largest hosts to FDI. However, FDI represented a very small fraction of domestic capital formation in the United States, and although certainly much higher in Canada, it was probably not of real significant until towards the very end of this period. It is also of importance to understanding the development of this region that in North America, FDI was relatively less important than other types of long-term capital flows. By way of contrast, during the 1880s when the nominal value of British owned enterprises operating in Latin America rose from 50 million pounds to 230 million pounds, over 40 per cent went to Argentina and Uruguay, which were among the most advanced parts of the continent. Although FDI in this region represented a much greater share of domestic investment, this was unable to establish a more dynamic growth path. Thus a large TNC presence in the world economy does not, by itself, establish FDI as an engine of economic growth. Rather, it seems more likely that FDI, like trade, was helping to reinforce a pattern of uneven development in the world economy.

A possibly more significant determinant of economic growth was the ability of economies to generate and absorb new technologies. Much like the current era, the period before the First World War was one of tremendous technological change. Moreover, new sources of power, new modes of transportation, new materials and new consumer products were associated with institutional changes at the enterprise level and in the organization and location of industry which were an integral part of a new 
Table 8

The pattern of trade policy reform, exports and growth in selected European countries (Annual growth rates based in three-year annual average) $^{\mathrm{a}}$

\begin{tabular}{|l|c|c|c|c|c|c|c|}
\hline & \multirow{2}{*}{$\begin{array}{c}\text { Date of } \\
\text { policy } \\
\text { change }\end{array}$} & \multicolumn{2}{|c|}{$\begin{array}{c}\text { Ten-year period } \\
\text { preceeding } \\
\text { protectionist move }\end{array}$} & \multicolumn{2}{|c|}{ Feriods following protectionist move } \\
\cline { 5 - 8 } & & Exports & GNP & Exports & GNP & Exports & GNP \\
\hline & 1887 & 4.9 & 1.2 & 2.3 & 2.0 & 2.7 & 2.8 \\
\hline Belgium & 1889 & 1.4 & 3.3 & 4.3 & 3.8 & 4.1 & 3.0 \\
\hline Denmark & 1892 & 2.1 & 1.2 & 1.9 & 1.3 & 2.7 & 1.5 \\
\hline France & 1885 & 3.0 & 1.3 & 2.4 & 3.1 & 5.2 & 2.9 \\
\hline Germany & 1887 & 0.4 & 0.7 & 1.7 & 0.5 & 4.5 & 2.7 \\
\hline Italy & 1888 & 3.4 & 1.5 & 2.8 & 3.5 & 2.4 & 3.3 \\
\hline Sweden & 1887 & 0.4 & $\ldots$ & -0.6 & $\ldots$ & 3.8 & $\ldots$ \\
\hline Switzerland & 1889 & 3.0 & 1.1 & 2.6 & 2.3 & 3.7 & 2.3 \\
\hline $\begin{array}{l}\text { Continental } \\
\text { Europe }\end{array}$ & & & & & & & \\
\hline
\end{tabular}

Source: $\quad$ Bairoch (1993).

a Average of three years preceeding the period, including the year when the policy change was made.

notion of modernity and progress. However, only a few countries occupied a leadership role in the area of technology. Indeed, at the beginning of the globalization era, only industry in the United Kingdom had been visibly effected by new technologies; for developed countries as a whole, less than one fifth of industrial production was associated with these new technologies. This situation had changed dramatically by the end of the period (table 9). This was part of a cumulative dynamic related to structural changes towards more high-technology industries (such as chemicals and engineering products) which were also among the most rapidly expanding areas of trade (Maizels, 1963, ch. 7). Thus, successful catching-up for most countries depended upon their gaining access to new technologies and ensuring that these played a role in enhancing the competitiveness of their industries through productivity growth.

However, if technological progress was an important source of economic growth, it was not an exogenous one. Rather, focusing on technological progress highlights the role of two central elements in the growth dynamics of the period which are often downplayed or overlooked altogether when too great an emphasis is placed on globalization tendencies. On the one hand, during this period the State became a much more active agent in technological change. This was most visible in its organization of national transportation and telecommunication networks, which not only were themselves industries 
Table 9

The share of new technology industries ${ }^{\mathrm{a}}$

in the total manufacturing output by regions, 1830-1913

(Percentage)

\begin{tabular}{|l|c|c|c|c|}
\hline & United Kingdom & $\begin{array}{c}\text { Other developed } \\
\text { countries }\end{array}$ & $\begin{array}{c}\text { Third world } \\
\text { (including } \\
\text { Japan) }\end{array}$ & $\begin{array}{c}\text { World } \\
\text { (including } \\
\text { Japan) }\end{array}$ \\
\hline 1830 & $32-40$ & $6-10$ & $0-1$ & $4-6$ \\
\hline 1860 & $60-70$ & $18-24$ & $0-1$ & $17-23$ \\
\hline 1880 & $62-74$ & $30-38$ & $1-3$ & $30-38$ \\
\hline 1900 & $68-78$ & $49-57$ & $4-9$ & $49-56$ \\
\hline 1913 & $72-80$ & $55-65$ & $10-19$ & $54-62$ \\
\hline
\end{tabular}

Source: Bairoch (1982), p. 288

$\boldsymbol{a}$ The concept of "new technologies" is inevitably rather rough. Our estimate of their importance in each region and period is based not only on distinctions made between sectors, but also within sectors. In the case of cotton, for example, we have used a different "new technology" weighting factor for each region and in each period for spinning and for the rest of the operations of the sector. Although these percentages have been derived from a huge mass of direct and indirect information, they are of course only approximations. Still, because of thee emergence of new sectors within traditional industries, it is likely that the figures are biased in favour of the first industrialisers.

at the frontier of technological progress but had extensive links to other related new industries, such as steel and engineering. But, in addition, there was also growing State involvement in the area of technological progress through the creation of demand for new product, including in emerging military complexes (Hobsbawm, 1994b, p. 308), as well as more direct funding of technical education and research activities (Freeman, 1989). On the other hand, because technological change is to a significant degree embodied in capital goods, it is closely related to the process of capital accumulation.

There seems little doubt that capital accumulation accelerated in the late 19th century in line with the needs of late industrialization. The United Kingdom's industrial leadership had been established with a rate of capital formation that never exceeded 10 per cent of national income and supported by a financial system that evolved very slowly (see Deane, 1961; Pollard, 1964; Studart, 1995). By contrast rates of capital formation in the late industrializing countries rarely fell below 10 per cent and in some cases exceeded 20 per cent (Panic, 1992, table 3.1). This more demanding investment regime involved institutional changes, among which closer links between finance and industry were, undoubtedly central to the growth dynamics of late industrializing countries. We have criticised earlier the idea that globalization in the pre 1913 era was one of weakening States. Rather, as Schumpeter recognized in the case of German development, bridging the institutional hiatus with the leading industrial economies and 
establishing a viable late industrialization path often involved close collaboration between the State and financial and industrial interests:

In some instances the bankers initially perceived new opportunities for investment and suggested methods of exploiting them. More important, however, were entrepreneurial tasks that were allied with financial ends. Frequently, interested bankers obtained government approval and support for the projects of others (Schumpeter, 1939, p. 178).

Similar developments can be found in Sweden, one of the most successful late industrializing economies of the late 19th century and in Japan where "large banks were increasingly important in financing both the initial and the continued development of large-scale enterprise, based on high indebtedness and stable interest rates" (Studart, 1995, p. 73). In this context, although it is probably fair to say that international capital flows were more cause than effect of successful industrialization, they were important - and in some cases critical - in sustaining the growth momentum in some of the core industrializing economies (Panic, 1992, p. 93; O'Rourke and Williamson, 1995, pp. 23-28).

Perhaps more important in terms of the overall direction of the world economy during this period was the strong complementarity between capital exporting and importing countries. On the one hand, growth in the core industrial economies not only generated excess savings in search of profitable outlets, but also growing markets for food products and raw materials. On the other hand, a group of land and raw material abundant economies in the Western Hemisphere and Oceania lacked the capital to fully exploit these resources. Because these economies had some of the infrastructural and institutional prerequisites to attract and absorb large inflows of capital and labour, the integration of financial markets generated the relative concentration of international capital flows discussed above. It is worth noting in this context, that large capital outflows were not always seen as an advantage to late industrializers. Indeed the disadvantages of such outflows - which had earlier been raised by Adam Smith and David Ricardo (Panic, 1988, ch. 7) - were a concern of policy makers in both Germany and (although to a lesser extent) France during this period, who tried to discourage such outflows or a least sought ways to tie them more closely to export orders (Bloomfield, 1968, p. 2).

What this suggests is that domestic capital formation was closely associated with various international pressures in a process of uneven development in the world economy. Essentially, the emergence of a group of countries with a strong growth dynamic gave shape to an internationally integrated monetary and economic framework. These developments were reinforcing; the more successful a country was in sustaining a high rate of growth relative to the rest of the world the more likely it was to attract international investment and sustain a rapid rate of industrialization. Even in those countries where there was a close association between the export dynamic and capital inflows, such as the white settler economies, powerful domestic forces on the supply and demand side were an equally important ingredient of economic growth (Bloomfield, 1968, p. 5). 
For those countries unable to establish such a cumulative growth dynamic, speculative capital flows were more likely to become a destabilising element. Certainly this was true in much of Latin America, where unsustainable financial flows could quickly give way to deflationary pressures, debt crises, a reduction in imports, particularly of capital goods, and a significant slowdown in growth rates (Marichal, 1989). An interesting case from the globalization era is Argentina where rapid liberalization of trade and finance in the late 1880s, disturbed a more balanced and stable development path. As described by Marichal, an initial period of State-building in the 1860s and 1870s, gave way to a laissez-faire ideology under domestic political pressures generating an explosive but largely speculative increase in capital inflows, particularly in real estate. The subsequent crisis sparked a minor banking crisis in Europe with the downfall of Barings Brothers. But in Argentina, austerity measures, falling real wages and the sale of State enterprises to foreign investors destroyed the growth dynamic and, moreover, had a negative spillover effect on other economies in the region:

\footnotetext{
"... the crisis of 1890 subjected the Argentine State to the dictates of the international banks that imposed severe financial conditions on both the national and the provincial governments in order to guarantee that they would recoup their loans and to assure the profitability of allied enterprises, such as British railway firms. At the same time, the European bankers took advantage of the failure in 1890 of numerous Argentine-owned enterprises, public and private, to further consolidate the dominant position of foreign capital in key spheres of the Argentine economy. And after the turn of the century they promoted a renewed burst of capital exports to the Rio de la Plata region, coordinating their strategies closely with commercial, railway and industrial magnates interested in expanding their interest there. This trend was common to many other Latin American nations as international bankers promoted a new and powerful wave of loans and direct investments that continued to run strong until World War I" (Marichal, 1989, pp. 169-70).
}

\section{CONCLUSION}

The issues surrounding globalization involve much more than measuring the extent of cross-border economic exchanges and their interlinkages. The real questions concern whether such exchanges have already eroded the ability of States to manage their economies and whether the removal of State responsibility over the direction of economic activity is a welcome development. An increasingly prominent version of the globalization thesis answers both questions positively. In this paper we have sought to challenge this strong globalization thesis by looking at changes in the world economy before the First World War. This has become a favoured vantage point for those observers who see in contemporary developments a recovery of an earlier globalization trend, interrupted for half a century by a series of, largely undesirable, economic and political events.

The evidence presented in this paper confirms the sceptical view of an altogether new globalizing world. However, in light of the profound social, political and economic changes that have characterized the short 20th century, the idea that we are simply recovering a trend of global economic integration broken by two world wars and a perverse era of State management is not convincing. To take two of 
the most prominent elements in the contemporary globalization debate, the liberalization of trade and the diminishing role of the State, from our survey of trends in the half century before 1913, these can best be described as historical myths. Perhaps even more significantly, we do not find evidence to support the idea that this earlier period was a golden age of economic growth and rapid convergence. Moreover, industry, which was the dynamo of economic growth in this period appears, was much less influenced by international factors than other sectors and was also an important source of divergence across the world economy. In this respect, we have also suggested that the internationalization of finance capital, which dominated the earlier globalization process as much as in the contemporary era, appears to be strongly related to a process of uneven development, often reinforcing existing differences in the world economy rather than bringing about convergence.

While modern capitalism is an expanding system whose origins lie in the dynamic processes of investment and innovation, these dynamic processes are neither abstract nor spontaneous, but channelled and shaped by particular institutional arrangements and policy interventions. Although the institutional changes which have taken place over the intervening three-quarters of a century since 1913 exclude any simple policy lessons across the two episodes of globalization, the broad finding that policies did effect important and lasting change, particularly in the spread of industrial activity in the late 19th century, is worth emphasising. In this respect it is wrong to describe State-led industrialization as a product of the post Second World War era. Rather, the combination of rising tariffs, support for technological upgrading and extensive State-borrowing on international capital markets were already important ingredients of economic development in the 19th century era of globalization. But understanding, why some countries were able to harness internationalization to a successful process of catching-up cannot be restricted to a question of appropriate policies and the presence of a good (or bad) State. The wider institutional dynamics which are part of this process are, for better or worse, the product of social and political actors, and link changes in international forces to the context of political economy. 


\section{REFERENCES}

AKYÜZ, Yilmaz(1995), "New trends in Japanese trade and FDI: Post-industrial transformation and policy challenges", paper given at WIDER Conference on Transnational Corporations and the Global Economy, Kings College, Cambridge, UK, September 1995.

BAIROCH, Paul (1976), Commerce Exterieur et Developpement Economique de l'Europe au XIXe Siecle (Paris-La Haye: Mouton).

(1982), "International industrialisation levels from 1750 to 1980", The Journal of European History, 2, pp. 269-333.

(1989), "European trade policy, 1815-1914", in P. Mathias and S. Pollard (eds), The Cambridge Economic History of Europe, Vol. VIII, pp. 1-160.

(1993,) Economics and World History: Myths and Paradoxes (London: Harvester).

_ (1996a), "World's gross national product, 1750-1995 (Computations, estimates and guesses)", mimeo (Geneva).

_ (1996b), "Globalization, myths and realities: One century of external trade and foreign investment", in R. Boyer and D. Drache, (eds), States Against Markets: The Limits of Globalisation (London: Routledge).

BAIROCH, Paul and B. ETEMAD (1985), Structure par Produits des Exportations dur Tiers-Monde, 1830-1937 (Geneve: Droz).

BANDEIRA DE MELLO, A. (1935), Politique Commericiale du Bresil (Rio de Janeiro).

BATOU, Jean (1990), Cent Ans de Resistance du Sous-Developpement (Geneva: Droz).

BLOOMFIELD, Arthur (1968), Patterns of Fluctuations in International Investment Before 1914, No. 21 (Princeton University: Princeton Studies in International Finance).

BROWN, R. and D. JULIUS (1994), "Is manufacturing still special in the world order", in R. O'Brien (ed.), Finance and the International Economy (Oxford: Oxford University Press).

BRYANT, Ralph (1980), Money and Monetary Policy in Interdependent Nations (Washington, DC: Brookings Institution).

CABLE, Vincent (1995), "What future for the state?", Daedalus, Spring, pp. 23-53.

CAMERON, Ronaldo (1985), "A new view of European industrialisation", The Economic History Review, 1, pp. 1-23.

CHANG, Ha-Joon (1995), "TNCs and strategic industrial policy", paper given at WIDER Conference on Transnational Corporations and the Global Economy, Kings College, Cambridge, UK, September 1995.

CHANG, Ha-Joon and R. KOZUL-WRIGHT (1994), "Organising development: Comparing the systems of entrepreneurship in Sweden and South Korea", The Journal of Development Studies, 4, pp. 859-891.

CHANG, Ha-Joon and B. ROWTHORN (1995), "Introduction" in Chang, H-J and B. Rowthorn, (eds), The Role of the State in Economic Change (Oxford: Clarendon Press).

DEANNE, Phylis (1961), "Capital formation in Britain before the railway age", Economic Development and Cultural Change, IX.

DUNNING, John (1984), "Changes in the level and structure of international production: The last one hundred years", in M. Casson (ed.), The Growth of International Buisiness (London: Allen and Unwin).

EDWARDS, Sebastien (1993), "Openness, trade liberalization, and growth in developing countries", Journal of Economic Literature, Vol. XXXI, No. 3, pp. 1358-1393.

ELMSLIE, Brian and W. MILBERG (forthcoming), "The productivity convergence debate: A theoretical and methodological reconsideration", Cambridge Journal of Economics.

FREEMAN, Christopher (1989), "The third Kondratieff wave: Age of steel, electrification and imperialism", in Kihlstrom et al. (eds.), Festchrift in Honour of Lars Herlitz (Gothenburg).

GORDON, David (1988), "The global economy: New edifice or crumbling foundation?", New Left Review.

HOBSBAWM, Eric (1994a), Age of Extremes: The Short Twentieth Century, 1914-1991 (London: Michael Joseph). (1994b), Age of Empire 1875-1914 (London: Abacus).

HENDERSON, David (1992), "International economic integration: Progress, prospects implications", International Affairs, No. 4, pp. 633-653.

IMF (1994), World Economic Outlook (Washington, DC: International Monetary Fund).

KENWOOD, A.G. and A.L. LOUGHEED (1994), The Growth of the International Economy, 1829-1990, third edition (London: Routledge).

KOZUL-WRIGHT, Richard (1995a), "Transnational corporations and the nation state", in J. Mitchie and J.G. Smith (eds.), Managing the Global Economy (Oxford: Oxford University Press). 
KOZUL-WRIGHT, Richard (1995b), "The myth of Anglo-Saxon Capitalism: Reconstructuring the history of the American State", in H.-J. Chang and R. Rowthorn (eds.), The Role of the State in Economic Change (Oxford: Clarendon Press).

KREGEL, Jan (1994), "Capital flows: Globalization of production and financing development", UNCTAD Review 1994, pp. 23-38.

KRUGMAN, Paul (1995), "Growing World Trade: Causes and Consequences", Brookings Papers on Economic Activity, 1, pp. 327-377.

LEAGUE OF NATIONS (1945), Industrialization and Foreign Trade (Geneva: United Nations).

MADDISON, Angus (1989), The World Economy in the Twentieth Century (Paris: OECD).

MAIZELS, Alfred (1963), Industrial Growth and World Trade (Cambridge: Cambridge University Press).

MARICHAL, C. (1989), A Century of Debt Crises in Latin America (Princeton: Princeton University Press).

MILBERG, William (1995), "Markets, states and economic growth", paper given at WIDER Conference on Transnational Corporations and the Global Economy, Kings College, Cambridge, UK, September 1995.

MITCHIE, Jonathan and M. KITSON (1995), "Trade and growth: An historical perspective", in J. Mitchie and J.G. Smith (eds.), Managing the Global Economy (Oxford: Oxford University Press).

O'ROURKE, Kevin and J. WILLIAMSON (1995), "Around the European Periphery, 1870-1913: Globalization, schooling and growth", NBER Working Paper, No. 5392 (Cambridge, MA: National Bureau of Economic Research).

PANIC, Mica (1988), The National Management of the International Economy (London: Macmillan). (1992), European Monetary Union: Lessons from the Classical Gold Standard (London: Macmillan).

- (1995), "Transnationals, international interdependence and national economic policy", paper delivered at WIDER Conference on Transnational Corporations and the Global Economy, Kings College, Cambridge, UK, September 1995.

PETIT, Pascal (1995), "Transnational service corporations in the process of globalization", paper delivered at WIDER Conference on Transnational Corporations and the Global Economy, Kings College, Cambridge, UK, September 1995.

POLLARD, Sydney (1964), "Fixed capital formation in the industrial revolution in Britain", Journal of Economic History, 3, pp. 299-314.

RAYMENT, Paul (1983), "Intra-industry specialisation and the foreign trade of industrial countries", in S. Frowen (ed.), Contolling Industrial Economies (London: Macmillan).

SACHS, Jeffrey and A. WARNER (1995), "Economic reform and the process of global integration", Brookings Papers on Economic Activity, 1, pp. 1-118.

SCHUMPETER, Joseph (1939), Business Cycles (New York: McGraw-Hill).

STUDART, Rugerio (1995), Investment Finance in Economic Development (London: Routledge).

UNCTAD (1994), Trade and Development Report, 1994 (Geneva: United Nations).

UNCTAD (1995), Trade and Development Report, 1995 (Geneva: United Nations).

WILKINS, Mira (1995), "Transnational corporations: An historical evaluation", paper delivered at WIDER Conference on Transnational Corporations and the Global Economy, Kings College, Cambridge, UK, September 1995.

WOOD, Adrian (1994), North-South Trade, Employment and Inequality: Changing Fortunes in a Skill-Driven World (Oxford: Clarendon Press).

WORLD BANK (1994), The East Asian Miracle (Oxford: Oxford University). (1995), World Development Report 1995 (Oxford: Oxford University Press).

YATES, L.P. (1959), Forty Years of Foreign Trade: A Statistical Handbook with Special Reference to Primary Products and Under-developed Countries (London).

ZEVIN, R. (1988), "Are world financial markets more open? If so, why and with what effect?", paper delivered at WIDER Conference on Financial Openess, Helsinki, July 1988. 
UNCTAD Discussion Papers

*No. 20, October 1986

No. 21, February 1988

No. 22, February 1988

No. 23, January 1988

No. 24, April 1988

No. 25, February 1989

No. 26, June 1989

*No. 27, August 1989

No. 28, April 1990

No. 29, April 1990

No. 30, April 1990

No. 31, August 1990

No. 32, August 1990

No. 33, September 1990

No. 34, March 1991

No. 35, March 1991

No. 36, March 1991

No. 37, March 1991

No. 38, April 1991

No. 39, April 1991

No. 40, August 1991
Reinaldo GONÇALVEZ

R. ERZAN,

H. KUWAHARA,

S. MARCHESE \&

R. VOSSENAAR

Refik ERZAN \&

Guy KASENTY

Bruno LANVIN

Reinaldo GONÇALVEZ

Yilmaz AKYÜZ

Juan A. DE CASTRO

Juan A. DE CASTRO

Andrew J. CORNFORD

Jesko HENTSCHEL

Alice H. AMSDEN \& YOON-DAE EUH

Simon CHAPPLE

Harmon C. THOMAS

Juan A. DE CASTRO \& Serafino MARCHESE

R. de C. GREY

Simon CHAPPLE

Yilmaz AKYÜZ

Joseph Y. LIM

J. F. OUTREVILLE

Andrew J. CORNFORD

Yilmaz AKYÜZ \& Detlef J. KOTTE
UNCTAD, structural adjustment and structural change: In search of a comprehensive approach The profile of protection in developing countries

Products facing high tariffs in major developed market-economy countries: An area of priority for developing countries in the Uruguay Round

International trade in services, information services and development: Some issues

Export expansion, import liberalization and economic growth in Latin America: An analysis of foreign trade multipliers

Financial system and policies in Turkey in the 1980s

Determinants of protection and evolving forms of North-South trade

Protectionist pressures in the 1990s and the coherence of North-South trade policies

Notes on a possible multilateral framework for international trade in banking services

Availability of intermediate and capital goods in import-restrained debtor countries

Republic of Korea's financial reform: What are the lessons?

A sequence of errors? Some notes on the sequencing of liberalization in developing countries

The implications for developing countries' exports earnings growth of an increase in the share of imports by developing countries from each other: A simulation analysis

El Acuerdo de Libre Comercio entre Estados

Unidos y Canada y su impacto sobre el comercio de America Latina y El Caribe

"1992" Financial services and the Uruguay Round

Financial liberalisation in New-Zealand, 1984-90

Financial liberalization in developing countries: A neo-Keynesian approach

The Philippine financial sector in the 1980s

The use of computer technology in the insurance sector of developing countries

The Multilateral Negotiations on Banking Services: Context and selected outstanding issues

Financial policies in developing countries: Issues and experience 
No. 41, August 1991

No. 42, October 1991

*No. 43, February 1992

No. 44, July 1992

No. 45, July 1992

No. 46, July 1992

No. 47, August 1992

No. 48, August 1992

No. 49, October 1992

No. 50, November 1992

No. 51, December 1992

No. 52, December 1992

No. 53, December 1992

No. 54, January 1993

No. 55, February 1993

No. 56, March 1993

No. 57, April 1993

No. 58, April 1993

No. 59, May 1993

No. 60, July 1993

No. 61, July 1993

No. 62, July 1993

No 63, July 1993

No. 64, July 1993

No. 65, August 1993

No. 66, August 1993
Manuel R. AGOSIN

Georg KELL \& Jürgen RICHTERING

Yilmaz AKYÜZ

Cem SOMEL

Sebastian SCHICH

Raju J. SINGH

V. BHASKAR

Ha-Joon CHANG \& Ajit SINGH

Ajit SINGH

Ulrich HOFFMANN \& Dusan ZIVKOVIC

Sebastian SCHICH

Dwight H. PERKINS

Patricio MELLER

Trevor GARDNER

Alexandre R. BARROS

Yilmaz AKYÜZ

Alice H. AMSDEN

Celso ALMEIDA

Ali-Reza NIKPAY

Jean-Marc FONTAINE

Korkut BORATAV

Roberto FRENKEL

Machiko NISSANKE \& Priya BASU

Machiko NISSANKE \& Priya BASU

Ercan UYGUR

YilmazAKYÜZ
Trade policy reform and economic performance: A review of the issues and some preliminary evidence

Technology and competitiveness in the textile industry

On financial deepening and efficiency

Finance for growth: Lessons from Japan

Indebtedness, sovereign risk and the spread: The example of Hungary and the Euromarkets

An imperfect information approach to the structure of the financial system

Privatization and the developing countries: The issues and the evidence

Public enterprises in developing countries and economic efficiency

The stock-market and economic development: Should developing countries encourage stock-markets?

Demand growth for industrial raw materials and its determinants: An analysis for the period 1965-1988

Indebtedness, creditworthiness and trade finance and payment arrangements

China's 'gradual' approach to market reforms

Latin American adjustment and economic reforms: Issues and recent experience

The present economic situation in Zambia and the role of privatisation in improving its economy

Prospects for world sugar trade

Financial liberalization: The key issues

Structural macroeconomic underpinnings of effective industrial policy: Fast growth in the 1980s in five Asian countries

Development and transfer of environmentally sound technologies in manufacturing: A survey

Privatization in Eastern Europe: A survey of the main issues

Reforming public enterprises and the public sector in sub-Saharan Africa

Public sector, public intervention and economic development

Growth and structural reform in Latin America: Where we stand

Mobilization and allocation of domestic savings: A study on Bhutan

Mobilization and allocation of domestic savings: A case study on Nepal

Liberalization and economic performance in Turkey

Maastricht and fiscal retrenchment in Europe

* Out of stock. 
No. 67, September 1993

No. 68, September 1993

No. 69, September 1993

No. 70, October 1993

No. 71, October 1993

No. 72, October 1993

No. 73, November 1993

No. 74, November 1993

No. 75, November 1993

No. 76, December 1993

No. 77, January 1994

No. 78, January 1994

No. 79, February 1994

No. 80, February 1994

No. 81, March 1994

No. 82: WITHDRAWN

No. 83, May 1994

No. 84, May 1994

No. 85, July 1994

No. 86, July 1994

No. 87, July 1994

No. 88, August 1994

No. 89, September 1994

No. 90, October 1994

No. 91, October 1994
Cem SOMEL

Andrew CORNFORD

Sebastian SCHICH

Veena JHA, René VOSSENAAR \& Simonetta ZARRILLI

Adolfo CANITROT

Xiaoning J. ZHAN

\section{J.H. REICHMAN}

Priya BASU \& Norman GEMMELL

William W.F. CHOA

Ajit SINGH

Shigehisa KASAHARA

Jean K. THISEN

Kálmán KALOTAY \& Ana María ALVAREZ

Edouard DOMMEN

Juan A. DE CASTRO

YilmazAKYÜZ\& Andrew CORNFORD

David FELIX

S.M. SHAFAEDDIN

Raju J. SINGH

Thomas ZIESEMER

Sebastian SCHICH

Veena JHA \& Ana Paola TEIXEIRA

Manuel R. AGOSIN

YilmazAKYÜZ \& Charles GORE
The State in economic activity: Problems of economic policy-making

The role of the Basle Committee on Banking Supervision in the regulation of international banking

The level and volatility of external financial positions and the costs of export credit insurance

Ecolabelling and international trade

The exchange rate as an instrument of trade policy

North American economic integration and its implications for the exports of China and Hong Kong

Implications of the Draft TRIPS Agreement for developing countries as competitors in an integrated world market

Fiscal adjustment in the Gambia: A case study

The relevance of market structure to technological progress: A case study of the chemical industry

The Plan, the market and evolutionary economic reform in China

A rescue plan for the post-bubble Japanese economy: The establishment of the Cooperative Credit Purchasing Company

The European Single Market and its possible effects on African external trade

Emerging stock markets and the scope for regional cooperation

Développement durable: Mots-déclic

The internalization of external environmental costs and sustainable development

Regimes for international capital movements and some proposals for reform

Industrial development in East Asia: What are the lessons for Latin America?

The impact of trade liberalization on export and GDP growth in least developed countries

Bank credit, small firms and the design of a financial system for Eastern Europe

Economic development and endogenous terms-oftrade determination: Review and reinterpretation of the Presbisch-Singer Thesis

The payment arrangements in the trade of CEECs and LDCs between 1986 and 1994

Are environmentally sound technologies the

Emperor's new clothes?

Saving and investment in Latin America

The investment-profits nexus in East Asian industrialization 
No. 92, November 1994

No. 93, December 1994

No. 94, January 1995

No. 95, January 1995

No. 96, February 1995

No. 97, February 1995

No. 98, April 1995

No. 99, May 1995

No. 100, August 1995

No. 101, August 1995

No. 102, August 1995

No. 103, September 1995

No. 104, September 1995

No. 105, October 1995

No. 106, October 1995

No. 107, November 1995

No. 108, November 1995

No. 109, December 1995

No. 110, January 1996

No. 111, January 1996

No. 112, March 1996
Charles GORE

\section{J. F. OUTREVILLE}

XIE Ping

William W.F.CHOA

Alexandre R. BARROS

Ajit SINGH

Z. KOZUL-WRIGHT

Juan A. DE CASTRO

Roberto FRENKEL

R. KOZUL-WRIGHT \& Paul RAYMENT

J.C. DE SOUZA BRAGA M.A. MACEDO CINTRA $\&$ Sulamis DAIN

Toni HANIOTIS \&

Sebastian SCHICH

Robert ROWTHORN

Giovanni N. DE VITO

John EATWELL

Luisa E. SABATER

David FELIX

Urvashi ZUTSHI

H.A.C. PRASAD

Charles GORE

Djidiack FAYE
Development strategy in East Asian newly industrializing economies: The experience of postwar Japan, 1953-1973

Life insurance in developing countries: A crosscountry analysis

Financial services in China

The derivation of trade matrices by commodity groups in current and constant prices

The role of wage stickiness in economic growth

How did East Asia grow so fast? Slow progress towards an analytical consensus

The role of the firm in the innovation process

Trade and labour standards: Using the wrong instruments for the right cause

Macroeconomic sustainability and development prospects: Latin American performance in the 1990s

Walking on two legs: Strengthening democracy and productive entrepreneurship in the transition economies

Financing the public sector in Latin America

Should governments subsidize exports through export credit insurance agencies?

A simulation model of North-South trade

Market distortions and competition: the particular case of Malaysia

Disguised unemployment: The G7 experience

Multilateral debt of least developed countries

Financial globalization versus free trade: The case for the Tobin tax

Aspects of the final outcome of the negotiations on financial services of the Uruguay Round

Bilateral terms of trade of selected countries from the South with the North and the South

Methodological nationalism and the misunderstanding of East Asian industrialization

Aide publique au développement et dette extérieure: Quelles mesures opportunes pour le financement du secteur privé en Afrique? 